\title{
On the Limits of the Davidsonian Approach: The Case of Copula Sentences*
}

\author{
Claudia Maienborn \\ Humboldt University Berlin
}

\begin{abstract}
Since Donald Davidson's seminal work “The Logical Form of Action Sentences" (1967) event arguments have become an integral component of virtually every semantic theory. Over the past years Davidson's proposal has been continuously extended such that nowadays event(uality) arguments are generally associated not only with action verbs but with predicates of all sorts. The reasons for such an extension are seldom explicitly justified. Most problematical in this respect is the case of stative expressions. By taking a closer look at copula sentences the present study assesses the legitimacy of stretching the Davidsonian notion of events and discusses its consequences. A careful application of some standard eventuality diagnostics (perception reports, combination with locative modifiers and manner adverbials) as well as some new diagnostics (behavior of certain degree adverbials) reveals that copular expressions do not behave as expected under a Davidsonian perspective: they fail all eventuality tests, regardless of whether they represent stage-level or individual-level predicates. In this respect, copular expressions pattern with stative verbs like know, hate, and resemble, which in turn differ sharply from state verbs like stand, sit, and sleep. The latter pass all of the eventuality tests and therefore qualify as true "Davidsonian state" expressions. On the basis of these empirical observations and taking up ideas of $\operatorname{Kim}(1969,1976)$ and Asher $(1993,2000)$, an alternative account of copular expressions (and stative verbs) is provided, according to which the copula introduces a referential argument for a temporally bound property exemplification (= "Kimian state"). Considerations on some logical properties, viz. closure conditions and the latent infinite regress of eventualities, suggest that supplementing Davidsonian eventualities with Kimian states may yield not only a more adequate analysis of copula sentences but also a better understanding of eventualities in general.
\end{abstract}

\section{Introduction}

Semantic research over the past three decades has provided impressive confirmation of Donald Davidson's famous claim that "there is a lot of language we can make systematic sense of if we suppose events exist" (Davidson 1980: 137). Soon after they took the linguistic stage, it became clear that event arguments were not to be understood as confined to the class of action verbs, as Davidson originally proposed, but probably had a much wider distribution. Nowadays, scholars working in what has been called the Neo-Davidsonian paradigm, following Higginbotham $(1985,2000)$ and Parsons $(1990,2000)$, assume that any predicate may have such a hidden argument. That is, it is not only verbs, whether eventive or stative, that are taken to introduce Davidsonian eventuality arguments ${ }^{1}$, but also adjectives, nouns, and prepositions. Motivation for

* This study is based on parts of my Habilitation thesis (published as Maienborn 2003a). A previous version has appeared as (Maienborn 2003b). Thanks to Manfred Bierwisch, Philippa Cook, Johannes Dölling, Veronika Ehrich, Stefan Engelberg, Thomas Ernst, Werner Frey, Bart Geurts, Gerhard Jäger, Hans Kamp, Graham Katz, Manfred Krifka, Fred Landman, Ewald Lang, Anita Mittwoch, Susan Olsen, Barbara Partee, Benjamin Shaer, Arnim von Stechow as well as to the NELS 33 audience and three anonymous reviewers for many helpful suggestions and comments. Special thanks to Ben for checking my English.

1 Throughout this paper, I will use Bach's (1986) term "eventuality" as a cover term for events, processes and certain (viz. Davidsonian; see below) states. The notion "event", which is often understood in a broad sense, i.e., as a synonym for "eventuality", will be reserved (whenever possible) for events proper, i.e., accomplishments and

To appear in Theoretical Linguistics 
this move comes from the observation that all predicative categories provide basically the same kind of empirical evidence that motivated Davidson's proposal and thus call for a broader application of the Davidsonian analysis. The following remarks from Higginbotham \& Ramchand (1997) are typical of this view:

Once we assume that predicates (or their verbal, etc. heads) have a position for events, taking the many consequences that stem therefrom, as outlined in publications originating with Donald Davidson (1967), and further applied in Higginbotham $(1985,1989)$, and Terence Parsons (1990), we are not in a position to deny an event-position to any predicate; for the evidence for, and applications of, the assumption are the same for all predicates.

(Higginbotham \& Ramchand 1997: 54)

As these remarks indicate, Davidsonian eventuality arguments have apparently become something like a trademark for predicates in general. ${ }^{2}$

The goal of the present paper is to subject this view of the relationship between predicates and eventualities to real scrutiny. By taking a closer look at the simplest independent predicational structure - viz. copula sentences - I will argue that current Davidsonian approaches tend to stretch the notion of eventualities too far, thereby giving up much of its linguistic and ontological usefulness. More specifically, the paper will tackle the following three questions:

1. Do copula sentences support the current view of the inherent eventuality-relatedness of predicates?

2. If not, what is a possible alternative to an eventuality-based analysis of copula sentences?

3. What does this tell us about Davidsonian eventualities?

The paper is organized as follows: Section 2 recapitulates the core assumptions of the Davidsonian notion of events. Section 3 gives an overview of current eventuality-based analyses of copula sentences; of particular interest here are accounts of the well-known stage-level/individual-level predicate distinction. Section 4 examines the behavior of copula sentences with respect to some standard as well as some new eventuality diagnostics. Copular expressions will turn out to fail all of these tests, regardless of whether they represent stage-level or individuallevel predicates. In this respect, copular expressions pattern with stative verbs like know, hate, and resemble, which in turn differ sharply from state verbs like stand, sit, and sleep. The latter pass all of the eventuality tests and therefore qualify as true "Davidsonian state" expressions. On the basis of these observations, section 5 provides an alternative account of copular expressions (and stative verbs), which combines Kim's $(1969,1976)$ notion of property exemplifications with Asher's (1993, 2000) conception of abstract objects. Specifically, I will argue that the copula introduces a referential argument for a temporally bound property exemplification

achievements in Vendler's (1967) terms. Other labels for an additional eventuality argument that can be found in the literature include "spatiotemporal location" (e.g. Kratzer 1995) and "Davidsonian argument" (e.g. Chierchia 1995).

2 In fact, since Davidson's original proposal the burden of proof for postulating eventuality arguments seems to have shifted completely; see, e.g., Raposo \& Uriagereka (1995: 182): "it is unclear what it means for a predicate not to have a Davidsonian argument". 
(= "Kimian state"), implementing this proposal within a DRT framework. Finally, in section 6 I offer some concluding remarks, and suggest that supplementing Davidsonian eventualities with Kimian states may yield yield a more adequate analysis not only of copula sentences but also of eventualities.

\section{Eventualities: ontological properties and linguistic diagnostics}

What does it mean for a predicate to have a Davidsonian eventuality argument? What linguistic properties follow from its presence? And what means are available to detect these hidden arguments? Of course, none of these questions has so far received anything like a definitive answer, and many versions of the Davidsonian approach have been proposed, with major and minor differences between them. While I cannot discuss these differences here, it nevertheless seems safe to say that there is at least one core assumption in the Davidsonian approach one that is shared, either explicitly or implicitly, by most scholars working in this paradigm. This is that eventualities are, first and foremost, particular spatiotemporal entities (in the world). As LePore (1985: 151) puts it, "[Davidson's] central claim is that events are concrete particulars - that is, unrepeatable entities with a location in space and time."

As the past three decades' discussion of this issue has shown (see, e.g., the overviews in Lombard (1998), Engelberg (2000), and Pianesi \& Varzi (2000), it is notoriously difficult to turn the above ontological outline into precise identity criteria for eventualities. Let me mention just two prominent attempts to do so. Lemmon (1967) suggests that two events are identical just in case they occupy the same portion of space and time. Unfortunately, this notion of events seems much too coarse-grained, at least for linguistic purposes, since any two events that just happen to coincide in space and time would, on this account, be identical (see, e.g., Davidson (1969: 178)). Another proposal, that of Parsons (1990), attempts, to establish genuinely linguistic identity criteria $^{3}$ for events, but this attempt, in contrast, seems to yield a notion of events that is too finegrained (see Eckardt (1998: chap. 3.1)). What we are clearly still missing, then, are criteria of the appropriate grain for identifying eventualities. This is also the conclusion of Pianesi \& Varzi's (2000) discussion of the ontological nature of eventualities:

[...] the idea that events are spatiotemporal particulars whose identity criteria are moderately thin [...] has found many advocates both in the philosophical and in the linguistic literature. [...] But they all share with Davidson's the hope for a 'middle ground' account of the number of particular events that may simultaneously occur in the same place.

Pianesi \& Varzi (2000: 12)

We can conclude, then, that the search for ontological criteria for identifying eventualities will probably continue for some time. In the meantime, linguistic research will have to build on a working definition that is up to the demands of natural language analysis.

What might also be crucial for our notion of eventualities (besides their spatial and temporal dimensions) is their inherently relational character. Authors like Parsons (1990), Carlson (1998), Eckardt (1998), and Asher (2000) have argued that eventualities necessarily

3 Parsons (1990: 157): "When a verb-modifier appears truly in one source and falsely in another, the events cannot be identical." See Engelberg (2000: $221 \mathrm{ff}$ ) for a criticism of Parsons' attempt to define an ontological category by linguistic means. 
involve participants serving some function. ${ }^{4}$ In fact, the ability of Davidsonian analyses to make explicit the relationship between eventualities and their participants, either via thematic roles or by some kind of decomposition, is certainly one of the major reasons for the continuing popularity of such analyses among linguists. This feature of Davidsonian analyses is captured by the statement in (1), which I will adopt as a working definition for subsequent discussion.

\section{Davidsonian notion of eventualities:}

Eventualities are particular spatiotemporal entities with functionally integrated participants.

I take (1) to be the core assumption of the Davidsonian paradigm. ${ }^{5}$ Let us explore (1) and its implications for natural language a little further.

Several ontological properties follow from (1). Being spatiotemporal entities in the world, eventualities can be perceived, and they have a location in space and time. In addition, given the functional integration of participants, eventualities can vary in the way that they are realized. These properties are summarized in (2):

Ontological properties of eventualities:

a. Eventualities are perceptible.

b. Eventualities can be located in space and time.

c. Eventualities can vary in the way that they are realized.

The properties in (2) can, in turn, be used to derive well-known linguistic eventuality diagnostics: As shown by Higginbotham (1983), perception verbs with infinitival complements are a means of expressing direct event perception and thus provide a suitable test context for eventuality expressions. On the basis of conditions (2b) and (2c), we also expect eventuality expressions to combine with members of the class of modifying expressions known as circumstantial modifiers. In particular, they combine with locative and temporal modifiers and with manner adverbials, instrumentals, comitatives and the like - that is, modifiers that elaborate on the internal functional structure of eventualities . These linguistic properties are summarized in (3).

Linguistic diagnostics for eventualities:

a. Eventuality expressions can serve as infinitival complements of perception verbs.

b. Eventuality expressions combine with locative and temporal modifiers.

c. Eventuality expressions combine with manner adverbials, instrumentals, comitatives, etc.

This, in a nutshell, is the Davidsonian view shared (explicitly or implicitly) by current eventuality-based approaches. Evidence that uncontroversial eventuality expressions (i.e. event verbs proper and process verbs) indeed conform to the diagnostics given in (3) can be found in any work on event semantics. I will therefore not repeat this evidence here. However, for sake of

4 For a discussion of apparent counter-examples see Carlson (1998: 38), Asher (2000), Maienborn (2003a: 48).

5 In section 5.2 below, I will be considering one way of weakening (1): namely, by assuming that only some but not all eventualities have a location in space (e.g. Dölling (1999)). I will argue, however, that this move seriously undermines the Davidsonian approach. 
comparison, I will take into account the murky class of stat(iv)e verbs when discussing the behavior of copula sentences.

The diagnostics in (3) provide a suitable tool for detecting hidden eventuality arguments and may therefore help us to assess the neo-Davidsonian claim that those arguments are not confined to a subclass of verbs but belong to any predicate. Before applying these diagnostics, let us have a look at some representative eventuality-based analyses of copula sentences.

\section{Eventuality-based analyses of copula sentences}

Generally speaking, copula sentences, on a Davidsonian analysis, refer to static eventualities that is, to states. 6 The result of combining the copula with the main predicate is a complex predicate of states. Opinions differ, however, when it comes to determining the source of the underlying eventuality argument. One class of analyses takes it to originate in the copula; another takes it to originate in the main predicate.

The assumption that the eventuality argument is introduced by the copula is advocated, for example, by Bierwisch (1988), Kamp \& Reyle (1993: 266-270), and Rothstein (1999). According to this view, English be, German sein and their counterparts in other languages are semantically poor full verbs that provide a verbal shell that is filled by the lexical content of the main predicate. As Rothstein (1999: 363) argues, be, "[1]ike any verb, [...] introduces a Davidsonian eventuality argument, but unlike lexical verbs, it does not express any property of that argument." This approach predicts, then, that combinations of copula and predicate behave like regular eventuality expressions.

The alternative view, according to which the eventuality argument is introduced by the main predicate, has been adopted and further developed by Kratzer (1995) and others against the background of the ongoing stage-level/individual-level debate. ${ }^{7}$ According to Kratzer's original proposal, stage-level predicates (SLPs) have an additional eventuality argument.while individual-level predicates (ILPs) do not. Thus, for example, we would (adopting a Parsons-style notation), assign the copula sentences in (4a), with the SLP tired, the semantic representation in (4b), whereas the copula sentence in (5a), with the ILP blond, would yield (5b). On this assumption, only SLPs pattern with eventuality expressions like sleep in (6).
a. Carol was tired.
b. $\quad \exists$ e [TIRED (e) \& THEME (e, carol)]

\footnotetext{
6 An exception is Rothstein (1999), who assumes that copular expressions are semantically underspecified with respect to the sort of eventuality argument that they introduce. Whether they actually refer to events, processes, or the default case of states is a matter of linguistic and extra-linguistic context. See Maienborn (2003a: chap. 6.2.2) for a discussion of Rothstein's approach.

7 The stage-level/individual-level distinction goes back to Carlson (1977), who draws on the tests and results of Milsark (1974, 1977); and is given an event-semantic treatment in Kratzer (1995). Stage-level predicates express (more or less) temporary or accidental properties, whereas individual-level predicates express (more or less) permanent or inherent properties. Following Kratzer (1995) and Diesing (1992), most current treatments of the stage-level/individual-level contrast take it to be a grammatical distinction that reflects a (still not fully understood) conceptual opposition; see Maienborn (2003a, 2003c, 2004) for an alternative, pragmatically oriented approach. An overview of the linguistic phenomena that have been associated with the stage-level/individuallevel distinction can be found in Higginbotham \& Ramchand (1997), Fernald (2000), and Jäger (2001).
} 
a. Carol was blond.

b. BLOND (carol)

a. Carol was sleeping.

b. $\exists \mathrm{e}[\operatorname{SLEEP}(\mathrm{e}) \&$ THEME (e, carol)]

Most advocates of the stage-level/individual-level distinction now agree that SLPs and ILPs alike have an extra eventuality argument; and different ways of accounting for their differences are currently being considered. For example, Chierchia (1995) and McNally (1998) have suggested that SLPs and ILPs refer to different types of eventualities (viz. location-dependent versus location-independent eventualities); while authors like Ramchand (1996) and Fernald (2000) have considered the possibility that SLPs are equipped (either structurally or lexically) with yet another eventuality argument besides the "regular" one shared by all predicates.

What is significant for our present purposes are not so much the numerous differences between these approaches as their commonalities. All of these accounts rely crucially on the idea that at least SLPs, and possibly all predications, introduce Davidsonian eventuality arguments. Copular expressions are predicted to behave like any other verbal expression in this respect. There is no grammatical distinction, then, in the way that a copular construction designates a property holding of an individual and the way that a main verb designates an eventuality and its participants. If a grammatically significant distinction exists at all, this rests on the difference between temporary/accidental and permanent/inherent properties and would be expected to affect copular and non-copular constructions alike.

\section{Evidence against eventuality-based accounts of copula sentences}

The linguistic diagnostics in (3) provide a way to test the predictions of eventuality-based accounts of copula sentences. In what follows, these eventuality tests will be applied to the German copula sein(see Maienborn 2003d for a discussion of the Spanish copula forms ser and estar).

\subsection{Infinitival complements of perception verbs}

The sentences in (7) and (8) show that SLP and ILP copula structures alike cannot appear as infinitival complements of perception verbs. This observation is an early one, due to Carlson (1977:125f).

$$
\text { a. * Ich sah Carol müde sein. }
$$
I saw Carol tired be.

b. * Ich hörte das Radio laut sein.

I heard the radio loud be.

c. * Renate sah Eva auf der Treppe sein.

Renate saw Eva on the stairs be.

a. * Ich sah Carol blond sein.

I saw Carol blond be.

copula $+S L P$

copula $+I L P$ 

b. * Ich sah Carol intelligent sein.
I saw Carol intelligent be.
c. * Ich sah Carol Französin sein.
I saw Carol french.FEM be.

If we compare these copula structures with full verbs, we can find a class of verbs - what Lakoff (1966) calls "statives" - that, in fact, display the same behavior. This is shown in (9).
a. * Ich sah die Tomaten $1 \mathrm{Kg}$ wiegen.
I saw the tomatoes $1 \mathrm{~kg}$ weigh.
b. * Ich hörte Carol die Antwort wissen.
I heard Carol the answer know.
c. * Ich sah meine Tante Romy Schneider ähneln.
I saw my aunt Romy Schneider resemble.

statives

However, there is also a class of descriptively stative verbs that do serve as infinitival complements of perception verbs, as (10) illustrates:
a. Ich sah Carol am Fenster stehen.
D-state verbs
I saw Carol at.the window stand.
b. Ich sah Carol warten / schlafen.
I saw Carol wait / sleep.
c. Die spanischen Eroberer sahen überall Gold glänzen.
The Spanish conquerers saw everywhere gold gleam.

I will call these verbs "Davidsonian state verbs" or "D-state verbs" for reasons that will become clear as we proceed. Included in this class are locative verbs like sit, stand, and lie as well as verbs like sleep, gleam, and wait.

The observation that stative verbs do not show up as infinitival complements of perception verbs has also been made by Katz (2000), although he does not take into account the behavior of the D-state verbs illustrated in (10). This leads him to draw the conclusion - which I believe to be incorrect - that the relevant difference can be traced back to the difference between states and events. As I will argue here, an adequate analysis of both eventuality expressions and statives requires us to recognize that the Davidsonian category of eventualities includes static eventualities (i.e., Davidsonian states) besides events and processes.

Let me add a remark on the verbs in (10) to make this point clearer. The classification of verbs like sit, stand, lie, sleep, and gleam has proven to be notoriously difficult. Vendler (1967) does not mention them and there appears to be no straightforward way to include them into one of the Vendler classes, since they are neither activity (or, more generally, process) expressions nor state expressions (i.e., statives).

The D-state verbs in (10) differ from process verbs in their subinterval properties: while processes involve a lower bound on the size of subintervals that are of the same type, states have no such lower bound. That is, states also hold at atomic times (see, e.g., Dowty 1979; Krifka 1989). If for a certain time interval I it is true that, for example, Eva is standing at the window, sleeping, or the like, this is also true for every subinterval of I. In this respect, D-state verbs pattern with statives.

A suitable linguistic test that distinguishes process (and event) expressions from stat(iv)e expressions is anaphoric reference by geschehen ('to happen'). While this proform can be used 
to refer to processes, as shown in (11), it accepts neither our D-state verbs nor statives as antecedents, as shown in (12) and (13), respectively:8

(11) a. Eva spielte Klavier.

Eva played piano.

b. Die Wäsche flatterte im Wind. The clothes flapped in.the wind.

Das geschah während...

process verbs

c. Die Kerze flackerte. The candle flickered.

This happened while...

(12) a. Eva stand am Fenster.

Eva stood at.the window.

b. Heidi schlief.

Heidi slept.

c. Die Schuhe glänzten.

The shoes gleamed.

d. Eva wartete auf den Bus.

Eva waited for the bus.

*Das geschah während...

This happened while...
D-state verbs

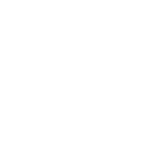

(13) a. Eva besaß ein Haus.

Eva owned a house.

b. Eva kannte die Adresse.

Eva knew the address.

c. Eva ähnelte ihrer Mutter.

Eva resembled her mother.

*Das geschah während...

statives

This happened while...

d. Eva hasste Mozart-Arien.

Eva hated Mozart arias.

Hence, the verbs in (10) and (12) cannot be subsumed under the category of process verbs. As such, they have sometimes been classified as a special subtype of statives, as in Dowty's (1979: 173ff) analysis of sit, stand, lie and the like as "interval statives" and Bach's (1986) distinction between "dynamic states" (e.g., sit, stand, lie) and "static states" (classical statives). Yet, our Dstate verbs differ from statives with respect to all of the relevant eventuality diagnostics, patterning in this respect with process and event verbs. This was already shown by the perception reports in (9) and (10), and will be given further empirical support in the following sections. All of these considerations, then, speak against a unified analysis of D-state verbs and statives.

Given this picture of D-state verbs and statives, we can now return to the analysis of copula sentences. Note, first, that the ill-formedness of copular expressions in perception reports like those in (7)-(8), and the well-formedness of D-state verbs like those in (10) cannot be simply a matter of interpretability. This is demonstrated by the sentences in (14), which presumably describe one and the same scenario. While (14a) is perfectly fine, (14b) is plainly unacceptable.

(14) a. Ich sah das Buch auf dem Tisch liegen.

I saw the book on the table lie.

8 See Maienborn (2003a: 59f) for some further qualifications. 
b. * Ich sah das Buch auf dem Tisch sein.

I saw the book on the table be.

This suggests that the inadmissibility of copular expressions as infinitival complements of perception verbs most likely has a grammatical source. ${ }^{9}$

In sum, both SLP and ILP copular expressions fail to pass our first eventuality test and in this respect pattern with stative verbs.

\subsection{Combination with locative modifiers}

What about the occurrence of copula constructions with locative modifiers?10 Sentences like those in (15) are generally understood to provide strong evidence that at least SLPs have an underlying eventuality argument, which may serve as a target for a locative modifier (e.g., Kratzer 1995; Chierchia 1995; Fernald 2000).

a. Carol war im Auto müde / hungrig / nervös.

copula + SLP

Carol was in.the car tired / hungry / nervous.

b.?? Carol war im Auto blond / intelligent / eine kluge Linguistin. copula + ILP

Carol was in.the car blond / intelligent / a smart linguist.FEM.

Adherents of the stage-level/individual-level distinction take data like these to be strong support for the claim that SLPs and ILPs differ with respect to "[their] ability to be located in space and time" (Fernald 2000: 24). ${ }^{11}$

However, there are good reasons to be skeptical of this claim. I have argued in Maienborn (2001) that there are three types of locative modifiers that can be distinguished on syntactic

9 Manfred Krifka (personal communication) has suggested the following pragmatic explanation of the unacceptability of infinitival copular expressions in perception reports. Sentences with copular SLPs like (i) might be grammatical but pragmatically infelicitous (signaled by ' $\S$ '), given the existence of a more economical copulafree variant like (ii).

(i) § Angela sah den Kanzler nackt sein.

Angela saw the chancelor naked be.

(ii) Angela sah den Kanzler nackt.

Angela saw the chancelor naked.

While this kind of reasoning is able to explain the pattern of acceptability in (i) and (ii), it cannot account for that in (iii) and (iv), where it is the structures with no copula forms that are ill-formed. This means that these cannot be blocking the structures that contain copula forms and thus that the latter should be acceptable, contrary to observation.

(iii)§ Angela sah den Kanzler anwesend sein / sah das Glas kaputt sein / hörte das Radio laut sein.

Angela saw the chancelor present be / saw the glass broken be / heard the radio loud be.

(iv)* Angela sah den Kanzler anwesend / sah das Glas kaputt / hörte das Radio laut.

Angela saw the chancelor present / saw the glass broken / heard the radio loud.

See Katz (2000: 405ff) and Maienborn (2003a: chap. 4.1.2) for arguments that the AP in (ii) is a secondary depictive predicate. Hence, constructions of type (ii) basically describe an event of perceiving an object (while it possesses some temporary property) rather than one of perceiving an eventuality.

10 The combination of copula constructions with temporal modifiers will be discussed in section 5.1.

11 Maienborn (2004) gives an overview of the proposed eventuality-based explanations and develops an eventuality-free alternative account for sentences of type (15) based on pragmatic economy principles. 
as well as semantic grounds. These three types, which I describe as "frame-setting", "external", and "internal", are indicated in (16).

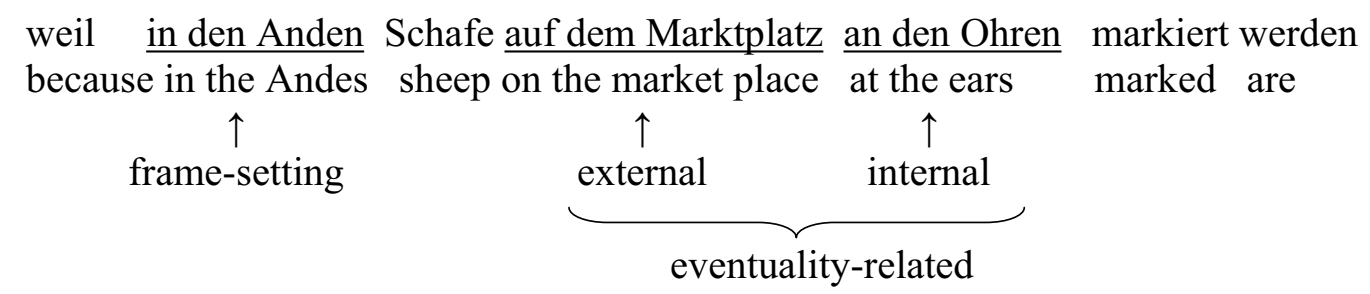

External and internal modifiers both have base adjunction sites inside the VP and relate to the VP's underlying eventuality argument. ${ }^{2}$ Frame-setting modifiers, on the other hand, are basegenerated outside the VP, within the verb's functional shell. Moreover, they are not eventualityrelated, but instead provide a semantically underspecified domain restriction for the overall proposition. 13 Given their semantic indeterminacy, frame-setting modifiers may be interpreted in several ways, depending on the respective discourse context. Take, for example, the copula sentence in (17), which has at least three readings, as paraphrased in $(17 \mathrm{a}-\mathrm{c})$. (The sentence adverb leider is used to indicate the VP boundary (see Diesing 1992; Frey 2000), thus forcing a frame-setting interpretation on the locative.)

$$
\begin{aligned}
& \text { weil Diego Armando Maradona in Italien (leider) verheiratet war. } \\
& \text { because Diego Armando Maradona in Italy (unfortunately) married was. }
\end{aligned}
$$

a. When he was in Italy, Maradona was married.

b. According to the laws in Italy, Maradona was married.

temporal reading

c. According to the belief of the people in Italy, Maradona was married.

Most importantly for our present purposes, frame-setting modifiers may be interpreted as restricting the topic time of a sentence (see Klein 1994), thus yielding a temporal reading, as illustrated in (17a). That is, temporally interpreted frame-setting modifiers restrict the time for which the speaker makes a claim and do not locate the verb's eventuality argument; they are therefore quite distinct from external modifiers. To see this more clearly, notice that a sentence such as (18), with the frame-setting locative in Italien 'in Italy' and the external locative in Frankreich 'in France', is not contradictory: the interpretation that it receives is 'during his stay in Italy, Maradona used to buy his suits in France'.

(18) In Italien kaufte Maradona seine Anzüge in Frankreich.

In Italy bought Maradona his suits in France.

12 External locative modifiers locate a verb's eventuality argument as a whole; internal locative modifiers add spatial information about some internal aspect of this eventuality; see Maienborn (2003c) for a compositional semantic account of these two types of modification.

13 Maienborn (2001) provides a series of syntactic, semantic, and prosodic criteria for determining the status of a locative modifier as eventuality-related or frame-setting. These are related to the behavior of locatives with respect to focus projection, quantifier scope, principle $\mathrm{C}$ effects, sentential negation and their interaction with sentence and frequency adverbs. See Frey \& Pittner (1998), Frey (2003) for a general discussion of the placement of adverbials in the German middle field. 
In the absence of conflicting information, as in (19), one might draw the inference that the buying events took place in Italy, but this kind of inference relies on world knowledge and may easily be overridden. In other words, such inferences are not licensed by the sentence's logical structure.

In Italien kaufte Maradona seine Anzüge mit Carol.

In Italy bought Maradona his suits with Carol.

Given the discussion above, the examples of copula sentences with locative modifiers given in (15) (and repeated below for convenience) might now be seen in a different light. The locatives in (15) do not belong to the class of eventuality-related modifiers but are instead frame-setting modifiers. More specifically, the observed difference between (15a) and (15b) is related to the ability of these locatives to receive a temporal reading.

a. Carol war im Auto müde / hungrig / nervös.

Carol was in.the car tired / hungry / nervous.

b.?? Carol war im Auto blond / intelligent / eine kluge Linguistin.

Carol was in.the car blond / intelligent / a smart linguist.FEM.

We can also see that the locatives in (15) are frame-setting rather than eventuality-related modifiers by making use of the eventuality diagnostics described in Maienborn (2001) (see fn. 13). One such diagnostic pertains to the behavior of these locatives with respect to sentential negation, which I describe below

Frame-setting locatives are not part of what the speaker asserts, but instead restrict the speaker's claim. Therefore, they are not in the scope of sentential negation. Eventuality-related locatives, in constrast, can be in the scope of sentential negation. This is reflected by the unmarked word order in (20).

$$
\text { frame-setting locative }>\text { negative adverb }>\text { eventuality-related locative }
$$

The negation of sentence (15a) yields (21a), with the locative preceding the negative adverb. (Note that in (21), major sentence accent is indicated by small capitals, and rising and falling accents by '/' and ' $/$ ', respectively.)

a. Carol war im Auto nicht MÜde.

sentential negation

Carol was in.the car not tired.

b. Carol war nicht im /Auto müde (... sondern während des VORltrags)

Carol was not in.the car tired (... but during the talk) no sentential negation

On a temporal reading of the locative frame in (21a), this sentence could be paraphrased as 'With respect to the time when she was in the car, it is not the case that Carol was tired.' The reverse order in (21b) does not support this reading but instead requires a contrastive interpretation, as indicated by the continuation given in parentheses. 14 here, the negative adverb takes narrow scope with respect to the locative frame: 'Not with respect to the time when she was in the car but with respect to some other time is it the case that Carol was tired.'

14 The obligatory contrastive interpretation for (21b) is consistent with the "bridge contour" described, for example, by Krifka (1998). 
Eventuality-related locatives display the opposite behavior. The order 'negative adverb > locative' in (22a) allows for sentential negation. (Paraphrase: 'It is not the case that Carol has played in the garden.') The reverse order in (22b) expresses only constituent negation of the verb.

a. Carol hat nicht im GARten gespielt.15

sentential negation

Carol has not in.the garden played.

b. Carol hat im Garten nicht ge/SPIELT (... sondern geschlalfen)

Carol has in.the garden not played (...but slept) no sentential negation

Data like (21) indicate, then, that the locatives in (15) are indeed frame-setting modifiers.

Furthermore, the observed contrast between the SLP variant in (15a) and the ILP variant in (15b) emerges only on a temporal reading of the locative frame. In other words, what the data in (15) really show is this: among the potential contextual specifications for frame-setting modifiers there appears to be one interpretation that excludes ILPs as main predicates. 16 However, these and similar data do not constitute evidence for the presence or absence of an underlying eventuality argument.

Frame-setting modifiers, as already noted, are not eventuality-related. Therefore, they cannot be used in eventuality diagnostics. If we want to check for underlying eventuality arguments we have to make sure that we are testing for real eventuality-related - that is, VPinternal - locative modifiers. Modifiers of this type, as associated with copular SLPs and ILPs, are given in (23) and (24), respectively. (The temporal adverbials prevent the locatives from being "rescued" and understood as temporal frame-setters.)
a. * Das Kleid ist auf der Wäscheleine nass. The dress is on the clothesline wet.
b. * Paul war (zu dieser Zeit) unter der Straßenlaterne betrunken. Paul was (at this time) under the street lamp drunk.
c. * Der Sekt ist (immer noch) im Wohnzimmer warm. The champagne is (still) in.the living room warm.

copula + SLP

15 If they are assigned a bridge contour, both (21a) and (22a) also allow for an interpretation of the negative adverb as constituent negation:

(i) Carol war im Auto nicht /MÜde, sondern schlecht geLAUNT\. Carol was in.the car not tired but bad-tempered.

(ii) Carol hat nicht im /GARten gespielt, sondern im HAUS\.

Carol has not in.the garden played but in.the house.

16 Apparently, a temporal reading of the locative frame forces us to interpret the main predicate as holding only temporarily. In Maienborn (2003a, 2004), I propose a pragmatic explanation for this temporariness effect in terms of Blutner's (2000) optimality-theoretic version of the Gricean maxims.

If the main predicate cannot be interpreted as holding only temporarily, as we find with ILPs, a framesetting locative may still be interpreted in a different way, e.g., along the lines of (17b-c), which gives us the preferred readings for (i) and (ii) below. That is, ILP sentences do, in fact, combine regularly with frame-setting locatives. There is nothing grammatically wrong with sentences like (15b); they only happen to exclude a temporal reading of the locative frame along the lines of (17a).
(i) In Deutschland ist Juhnke berühmt.
'Among people of Germany, Juhnke is famous.'
(ii) In Deutschland ist Juhnke weltberühmt.
In Germany is Juhnke world famous.
'According to the belief of people of Germany, Juhnke is world famous.' 
d. * Carol ist (gerade) im Auto müde.

Carol is (at the moment) in.the car tired.
a. * Carol war (die ganze Zeit) vor dem Spiegel eitel.
copula $+I L P$
Carol was (the whole time) in-front-of the mirror vain.
b. * Die CD ist in der Hülle rund.
The CD is in the case round.

The data in (23) and (24) are surprising for an eventuality-based approach of copula sentences. If either the copula or the main predicate did actually introduce an eventuality argument, we would expect a locative modifier expressing the location of this eventuality to be possible. A sentence like (23a), for example, should, on such an analysis, be able to indicate that there is a state of the dress being wet and that this state is located on the clothesline, as spelled out in the following representation.

$$
\exists \text { e [WeT (e) \& THEME (e, def-dress) \& LOC (e, ON (def-clothesline))] }
$$

Note that this would make perfect sense from a neo-Davidsonian perspective, which suggests that no deep conceptual or pragmatic reasons rule out such an analysis, at least in the case of copular SLPs. ${ }^{17}$ Yet no such interpretation is available for the sentences in (23). Even worse, combinations of copular expressions with VP-internal locative modifiers are clearly ungrammatical regardless of whether the main predicate is a SLP, as in (23), or an ILP, as in (24).

A final source of evidence that we see copula constructions - whether SLPs or ILPs pattern with statives rather than with $\mathrm{D}$-state verbs is given below:
a. * Die Tomaten wiegen neben den Zwiebeln $1 \mathrm{Kg}$.
The tomatoes weigh besides the onions $1 \mathrm{~kg}$.
b. * Carol weiß (gerade) an der Tafel die Antwort.
Carol knows (at the moment) at the blackboard the answer.

statives
a. Paul schläft (gerade)
im Auto.
D-state verbs
Paul sleeps (at the moment) in.the car.
b. Die spanische Armada lag bei Calais vor Anker.
The Spanish Armada lay near Calais at anchor.

As these sentences show, copula verbs display the same unacceptability as the statives in (26), and contrast with the D-state verbs in (27).

Summing up, closer inspection of locatives in copula sentences reveals no grammatical difference between copular SLPs and ILPs with respect to locative modifiers. Both combine with frame-setting locatives and both exclude eventuality-related locatives. Despite what has commonly been claimed - as reflected in the quotation from Fernald (2000) given above copular SLPs and ILPs do not differ in their (in)ability to be located in space.

17 One could probably argue that combining copular ILPs with eventuality-related locative modifiers as in (24) is pragmatically infelicitous. But such a move would not explain why the SLP variants in (23) are equally illformed. 


\subsection{Combination with manner adverbials and similar expressions}

The same picture emerges with manner modification. Copular expressions and statives do not combine with manner adverbials, comitatives and the like - that is, modifiers that elaborate on the internal functional structure of eventualities - whereas D-state verbs do, as (28)-(31) show.

a. * Carol war unruhig durstig.

copula + SLP

Carol was restlessly thirsty.

b. * Paul war friedlich / mit seinem Teddy / ohne Schnuller müde.

Paul was calmly / with his teddy/without dummy tired.

c. * Paul war reglos im Zimmer.

Paul was motionless in.the room.

(29) a. * Carol war mit ihrer Tante Vegetarierin.

copula $+I L P$

Carol was with her aunt vegetarian.FEM.

b. * Der Tisch ist stabil aus Holz.

The table is sturdily wooden (lit. 'from wood').

(30) a. * Maria ähnelt mit ihrer Tochter Romy Schneider.

statives Maria resembles with her daughter Romy Schneider.

b. * Paul besitzt sparsam/spendabel viel Geld. Paul owns thriftily / generously much money.

a. Paul schläft friedlich / mit seinem Teddy / ohne Schnuller.

D-state verbs Paul sleeps calmly / with his teddy / without dummy.

b. Carol saß reglos / kerzengerade am Tisch.

Carol sat motionless / straight.as.a.die at.the table.

Further evidence for this contrast - and for the presence of eventuality arguments in D-state verbs - is given in the contrast between (32) and (33). Sentence (32), which contains the D-state verbs lie and hold, nicely demonstrates the plausibility of assuming hidden eventuality arguments:

(32) Carol stand sicher auf der Leiter und hielt zur gleichen Zeit unsicher die Kiste.

Carol stood steadily on the ladder and held at.the same time unsteadily the box.

Clearly, it cannot be Carol, the referent of the subject noun phrase, who is both steady and unsteady at the very same time, since this would make (32) contradictory, which it is not. Rather, it is the state of Carol standing on the ladder that is steady and the (temporally coextensive) state of her holding the box that is unsteady (see Eckardt 1998).

If we turn now to the copula sentences in (33), it would seem to make perfect sense to interpret them in a similar fashion. 18

18 Note, e.g., that the attributive variant of (33a) is perfectly fine:

(i) Carol war eine sichere Alpinistin und eine unsichere Pianistin.

Carol was a steady alpinist.FEM and a unsteady pianist.FEM. 

a. * Carol war sicher Alpinistin und unsicher Pianistin.
Carol was steadily alpinist.FEM and unsteadily pianist.FEM.
b. * Carol war klaglos hungrig und zur gleichen Zeit jammernd durstig. Carol was uncomplainingly hungry and at.the same time complainingly thirsty.

Yet these sentences are clearly unacceptable, which indicates that neither the ILP variant in (33a) nor the SLP variant in (33b) introduces an eventuality argument with which a manner adverb could be associated.

Sentences like (34), at first sight, seem to provide counter-evidence to my claim that copula constructions do not combine with manner adverbials and similar expressions:
a. Carol war schnell in der Stadt.
Carol was quickly in the town.
b. Paul war mit Begeisterung Opa.
Paul was with enthusiasm grandpa.
c. Das Fenster war weit offen.
The window was wide(ly) open.

Yet, closer inspection suggests that they all involve some kind of non-compositional reinterpretation - an analysis given further support by their unacceptable counterparts in (35):
a. * Carol war langsam in der Stadt.
Carol was slowly in the town.
b.?? Paul war mit Begeisterung Verwandter (von Grit).
Paul was with enthusiasm relative (of Grit).
c.?? Die Höhle war weit offen.
The cave was wide(ly) open.

Sentence (34a), for example, can be understood as subject to an ingressive coercion, whereby the manner adverb schnell 'quickly' does not modify a state of Carol being in the city but an event of her going to the city. Similarly, the adverbial mit Begeisterung 'with enthusiasm' seems to trigger an agentive coercion in (34b): what Paul is enthusiastic about are the activities associated with being a grandfather. No such activities readily come to mind in the case of 'being a relative (of Grit)', making (35b) odd. Finally, despite first appearances, there is likewise no straightforward integration of the adverb weit in (34c), since its counterpart in (35c) should otherwise be fine. Roughly speaking, weit modifies the resultant object (Geuder 2000) of an opening event. What is further specified by weit in (34c) is not some presumed eventuality of the window being open, but the gap between the window and its frame that is the result of an event of opening the window. Caves, being natural openings, do not lend themselves to such an eventive coercion.

If copular expressions did introduce eventuality arguments in a systematic fashion, suitable manner modifiers should be able to associate with them directly, without requiring the kind of reinterpretations that we have just observed. 19

We may conclude that sentences such as (34)-(35) are based on (more or less plausible) non-compositional reinterpretations which are triggered by a sortal conflict between the modifier and the copula construction. Thus, sentences like these, though they seem to counterexemplify

19 For further discussion of these and other (apparent) counter-examples, see Maienborn (2003e). 
the claim that copula constructions do not combine regularly with manner adverbials and similar expressions, actually turn out to strengthen this claim.

\subsection{A new eventuality diagnostic: ein bisschen ('a little bit')}

In this section, I will suggest a new eventuality diagnostic based on the modifier ein bisschen 'a little bit'. In combination with a process verb like schwitzen 'to sweat', as given in (36), ein bisschen displays two readings. As a degree modifier, it indicates that the amount of sweat was small. As an eventive modifier, it indicates that the run-time of the process was short. (The eventive reading applies only to homogeneous eventualities, i.e., processes and D-states.)

$$
\text { Carol hat gestern ein bisschen geschwitzt. }
$$
Carol has yesterday a little bit sweated.

\section{degree and eventive reading}

When combined with D-state verbs, ein bisschen always supports the eventive reading, as shown in (37). Whether or not there is an additional degree reading depends on the verb meaning.

a. Carol hat ein bisschen geschlafen.
Carol has a little bit slept.

b. Paul hat ein bisschen im Garten gesessen. Paul has a little bit in.the garden sat.

c. Das Fenster hat ein bisschen offen gestanden. The window has a little bit open stood. eventive reading

eventive reading

degree and eventive reading

Strikingly, copula sentences - SLPs and ILPs alike - lack the eventive reading of ein bisschen and have only the degree reading. As we might expect, statives display the same behavior. This is illustrated in (38) and (39):

(38) a. Carol war ein bisschen müde / hungrig / schmutzig.

only degree reading

Carol was a little bit tired / hungry / dirty.

b. * Die Ampel war ein bisschen gelb.

The traffic light was a little bit yellow.

c. * Carol trug die Kiste selbst, denn sie war erst ein bisschen schwanger. Carol carried the box herself, because she was only a little bit pregnant.

d. Das Kleid war ein bisschen kurz. only degree reading The dress was a little bit short.

e. Die Telekom-Aktie war ein bisschen billig. only degree reading The Telekom share was a little bit cheap.

(39) a. * Nach ihrer 5. Heirat hieß Liz ein bisschen Burton. After her $5^{\text {th }}$ marriage was-named Liz a little bit Burton.

b. * (Kaufen Sie jetzt!) Diese Aktie kostet nur ein bisschen so wenig. (Buy now!) This share costs only a little bit so little.

c. Carol ähnelte ein bisschen ihrer Großmutter. only degree reading Carol resembled a little bit her grandmother. 
Notice that the eventive reading of ein bisschen would definitely make sense in these cases. If copula constructions or statives did introduce an eventuality argument, then we would expect the addition of ein bisschen to indicate that the respective state lasted for a short time. Yet the grammar does not appear to support such a reading.

Let me add a remark on the seemingly similar case of English for a little bit in copula sentences like (40), which were brought to my attention by Thomas Ernst (personal communication).

(40) a. Bill was quiet for a little bit (and then got rowdy again).

b. She was tired for a little bit (but then perked up).

Both the degree adverbial ein bisschen/a little bit (in its eventive reading) and the durational PP for a little bit locate their target referent within a short time interval. There are various reasons, however, to distinguish ein bisschen/a little bit from for a little bit. In particular, they differ wrt the sortal restrictions they impose on their target referent. While the degree adverbial ein bisschen/a little bit only combines with expressions of homogeneous eventualities (processes and $\mathrm{D}$-states), the for-PP is less restrictive, requiring its target referent only to have a temporal dimension. This condition apparently is fulfilled in copula sentences. The combination of copular constructions with durational adverbials like for a little bit and other temporal modifiers will be addressed in section 5.1.

Note furthermore that for a little bit has no German counterpart *für ein bisschen but is translated by für eine Weile or für kurze Zeit; see (41).

(41) Bill war *für ein bisschen / für eine Weile / für kurze Zeit ruhig.

Bill war for a little bit / for a while / for a short time quiet.

This crosslinguistic difference can be seen as a further hint towards the need for a separate treatment of ein bisschen/a little bit on the one hand and for a little bit on the other. We may conclude that the ability of ein bisschen to receive the eventive reading with a given predicate is a reliable diagnostic for the association of this predicate with a (homogeneous) eventuality argument.

\subsection{Taking Stock}

The various eventuality tests described in the preceding sections all produce the following results:

1. Copula sentences fail all of these eventuality tests, just as statives do.

2. Copular SLPs and ILPs exhibit no grammatically significant differences on these tests.

3. D-State verbs pass all of the eventuality tests.

Three conclusions can be drawn from these findings. First, there is no good reason to assume that copula constructions introduce a Davidsonian eventuality argument, regardless of whether they are classified as SLPs or ILPs. Thus, we definitely are "in a position to deny an event-position to (copula plus) any predicate", contra Higginbotham and Ramchand (1997), among others. 
Next, the borderline drawn by these eventuality diagnostics does not coincide with a difference between events and states (contra, e.g., Katz 2000, 2003). D-state verbs qualify as true eventuality expressions, denoting static Davidsonian eventualities.

Finally, based on the above results we may conclude that the grammar distinguishes sharply between eventualities, on the one hand, and properties holding of an individual (whether permanent or temporary), on the other.

If we take the Davidsonian notion of eventualities seriously - and the progress achieved by event semantics provides good reasons for doing so - we have little choice but to reject eventuality-based approaches to copula sentences. Eventuality arguments are, it seems, not as freely available as is currently assumed within the neo-Davidsonian paradigm.

\section{An alternative account of copula sentences}

\subsection{Evidence for an underlying argument}

If copula sentences do not introduce a Davidsonian eventuality argument, this raises two obvious possibilities: either these sentences do not introduce any referential argument at all, or they just refer to a different kind of entity. In this section, I will present some linguistic evidence in support of the latter possibility.20

First of all, copula structures clearly combine with different types of temporal modifiers, as (42) shows. (See also the remarks on the durational adverbial for a little bit in section 4.4.)

a. Carol war gestern / seit dem Morgen / zweimal / tagelang wütend. Carol was yesterday / since the morning / twice / for days angry.

b. Die 3 war gestern / seit diesem Tag / zweimal / jahrelang Pauls Glückszahl. The 3 was yesterday / since this day / twice / for years Paul's lucky number.

If we want to give (standard) temporal adverbials a straightforward analysis as intersective modifiers, in the spirit of Davidson, then the combination of copula plus main predicate should at least contribute a temporal argument. This might then serve as a target for temporal modification.

Secondly, data such as (43) indicate that copula constructions are subject to a particular kind of anaphoric reference. In (43a), for example, the anaphoric pronoun das refers back to some "state" of Carol being angry. Notice that das cannot be analyzed as a fact anaphor here, given that facts are atemporal (e.g. Asher 1993, 2000).

(43) a. Carol ist wütend. Das wird bald vorbei sein.

Carol is angry. This will soon over be.

b. Der Schlüssel war weg und das seit dem Wochenende.

The key was away and this since the weekend.

This suggests that copula plus main predicate indeed introduce an underlying argument that can be located in time and allows for anaphoric reference.

20 While the following considerations concentrate on copula constructions, focusing on the particularly intriguing case of copular SLPs, it should be clear from the results obtained in section 4 that the proposed analysis is intended to carry over to stative verbs. 
A further piece of evidence comes from the German anaphoric expression dabei (literally: 'thereat') illustrated in (44), which adds some accompanying circumstance to its antecedent.

(44) a. Es war kalt und dabei regnerisch.

It was cold and thereat rainy.

b. Carol war krank und lief dabei ohne Schal herum.

Carol was ill and walked thereat without scarf about.

c. Die Zwei ist eine Primzahl und dabei gerade.

The two is a prime number and thereat even.

Sentence (44b), for example, indicates that the "state" of Carol being ill is accompanied by (possibly iterated) events of Carol walking about without a scarf. Notice that the antecedent of dabei may also be introduced by a copular ILP like 'being a prime number' as in (44c). In Maienborn (2003a, 2003e), I argue (based on a variant of Parsons' (2000) "time travel" argument) that dabei does not express mere temporal overlap but relates to the substance of its antecedent. This calls for a reification of the denotatum of copula-predicate combinations.

In what follows, I will call the entities denoted by copula constructions (and stative verbs) "Kimian states" or "K-states".

\subsection{On the nature of Kimian states}

In the philosophical discussion initiated by Davidson's (1967) “invention" of events, Kim (1969, 1976) advocated an alternative view, according to which events should be understood as temporally bound property exemplifications. Kim views events as structural complexes that can be reduced to more primitive notions, as indicated in the following quotation:

What is essential is that we are assuming as primitives the three functors on events: 'is the constitutive property of', 'is the constitutive object of', and 'is the time of the occurrence of'. The theory states that just in case a substance $\mathrm{x}$ has property $\mathrm{P}$ at $\mathrm{t}$, there is an event whose constitutive object is $\mathrm{x}$, whose constitutive property is $\mathrm{P}$, and whose time of occurrence is $\mathrm{t}$ (the existence condition), and that events are identical just in case they have the same constitutive property, object, and time (the identity condition).

(Kim 1976: 161)

While there are good reasons to reject Kim's proposal as a substitute for the Davidsonian approach to eventualities summarized in (1)-(3) (cf., e.g., Engelberg 2000, Maienborn 2003a), Kim's alternative becomes more attractive if it is taken as a description of the entity referred to by copula constructions and stative verbs. More specifically, the copula analysis that I will be presenting below will combine Kim's approach with Asher's (1993, 2000) conception of $a b$ stract objects as mentally constructed entities.

According to Asher, abstract objects are introduced for efficient natural language processing and other cognitive operations but do not exist independently of them. Roughly speaking, abstract objects exist only because we talk and think about them. Asher (1993: 57f) assumes, in addition, that there is a spectrum of world immanence that spans real and abstract objects. At one pole we find eventualities, which are real things in the world, and at the other 
pole, propositions, which are entirely abstract objects. Facts occupy a position in between, as shown in (45): they are abstract objects but they are bound to certain worlds.

$$
\begin{gathered}
\begin{array}{c}
\text { Asher's spectrum of world immanence: } \\
\text { eventualities } \\
\text { [spatiotemporal entities] }
\end{array} \\
-\begin{array}{c}
\text { facts } \\
\text { [world bound] }
\end{array}
\end{gathered}
$$

In view of our preliminary assumptions about the referents of copular constructions, let us add some values along this spectrum by introducing K-states as a further type of abstract objects between eventualities and facts. K-states are bound to worlds and times, as indicated in (46).

\section{Locating K-states:}

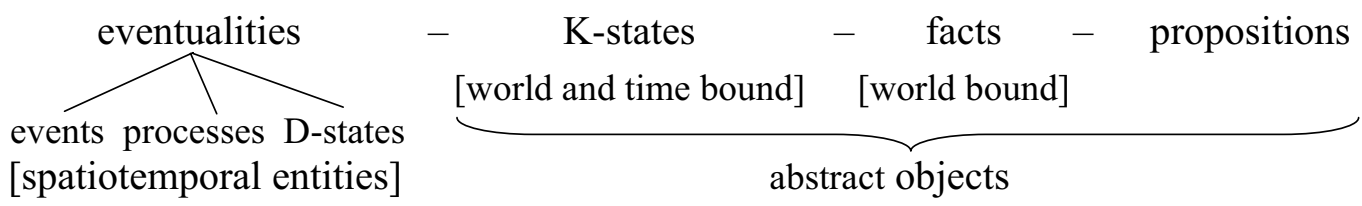

K-states have something in common with eventualities - both have a a temporal dimension, and with facts - both are abstract objects (which, as just noted, are mental constructs introduced primarily for efficient communication).

Against this background, K-states can be given the following working definition:

(47) Kimian states (K-states):

$\mathrm{K}$-states are abstract objects for the exemplification of a property $\mathrm{P}$ at a holder $\mathrm{x}$ and a time $\mathrm{t}$.

The tentative definition given in (47) is just a first step towards clarifying the nature of the entity referred to by copula constructions and stative verbs. Even so, several properties of K-states may be derived from it, as shown in (48):

(48) Ontological properties of K-states:

a. K-states, being abstract objects, are not accessible to direct perception and have no location in space.

b. K-states, being abstract objects, are accessible to (higher) cognitive operations.

c. K-states can be located in time.

(49) gives the corresponding linguistic diagnostics.

(49) Linguistic diagnostics for K-states:

a. K-state expressions cannot serve as infinitival complements of perception verbs and do not combine with locative modifiers.

b. K-state expressions are accessible for anaphoric reference.

c. K-state expressions combine with temporal modifiers. 
The outline of K-states given in (47)-(49) parallels the characterization of eventualities in (1)-(3). Taken together, they account for the significant differences that we have observed between the behavior of copular constructions (and stative verbs) and that of eventuality expressions.

The evidence presented in the preceding sections suggests, then, that copular constructions do indeed introduce an underlying argument, but one that is ontologically "poorer" than Davidsonian eventuality arguments. The entity referred to by statives cannot be perceived, located in space, or vary in its realization, but it can be located in time and may serve as an antecedent for anaphoric reference.

The present account views Davidsonian eventualities and Kimian states as belonging to two distinct ontological domains. Specifically, it argues against treating the entities that stative expressions refer to as a special subtype of Davidsonian eventualities. The latter approach has recently been defended by Dölling (1999), who distinguishes two subtypes of states within the domain of eventualities:21 states that have a location in space and states that do not. The former subtype corresponds to our Davidsonian states, the latter to what I have called Kimian states.On Dölling's account, Kimian states would be just a special sort of static eventualities - states, that, according to our findings in section 4 , can be neither perceived nor located in space and cannot vary in the way that they are realized. In my view, such a move seriously undermines the basic Davidsonian approach, forcing us to abandon the well-motivated understanding of eventualities as spatiotemporal entities (with functionally integrated participants), which I have recapitulated in section 2. What would be the smallest common denominator for events, processes, and Davidsonian states, on the one hand, and Kimian states, on the other? If we were to adopt such a liberal perspective, the only thing we could say about eventualities would be that they have a temporal dimension and some further content. That is, Kimian states would set the tone for the whole category of eventualities - a clearly undesirable result. (See Maienborn (2003e) for further drawbacks.)

Trying to adapt the ontological category of Davidsonian eventualities in such a way that Kimian states can be subsumed under them inevitably requires us to give up the greatest benefits of the Davidsonian approach. It seems worthwhile, then, to continue to explore the idea of supplementing the ontological category of Davidsonian eventualities with Kimian states, in order to account adequately for both eventuality expressions and statives.

\subsection{A K-state-based account of copula sentences in DRT}

In this section, I will sketch a K-state-based account of copula sentences within the framework of Discourse Representation Theory (DRT; Kamp 1981, Kamp \& Reyle 1993).22

Let us first have a look at the derivation of a DRS for an eventuality sentence like (50).

21 Bach's (1986) division of states into "dynamic" and "static" states and Dowty's (1979) identification of "interval statives" as a subclass of state expressions point us in the same direction; on this, see section 4.1.

22 Cf. Asher (1993) for the compositional DRT variant with $\lambda$-abstraction employed here. I use a flat notation for DRSs: discourse referents are separated from DRS conditions by a straight line; see the notational convention in (i).

(i) Notation: $\lambda \mathrm{y} \lambda \mathrm{x} \ldots$ [discourse referents $\mid$ DRS conditions]

Variables are sorted as follows. $\mathrm{x}, \mathrm{y}, \mathrm{u}, \mathrm{v}$ : individuals; $\mathrm{z}$ : K-states; e: eventualities; s: K-states $\cup$ eventualities; P, Q, R: first-order predicates. 
Carol schläft.

Carol is sleeping.

A slightly simplified version of the relevant lexical entries is given in (51). (The contribution of tense, aspect, mood etc. will be omitted; see Maienborn (2003a, 2003d) for a more detailed account.)
a. Carol:
[v $\operatorname{CAROL}(\mathrm{v})]$
b. schlafen:
c. Infl:
$\lambda \mathrm{x} \lambda \mathrm{e}[\operatorname{SLEEP}(\mathrm{e}), \operatorname{THEME}(\mathrm{e}, \mathrm{x})]$
$\lambda \mathrm{P}[\mathrm{s} \mid \mathrm{P}(\mathrm{s})]$

For the sake of simplicity, I will assume that a proper name introduces a discourse referent $\mathrm{v}$ into the universe of discourse, as in (51a). The verb to sleep is represented by the predicative DRS in (51b). And the chief contribution of Infl in (51c) is that of introducing a discourse referent $\mathrm{s}$ (either eventuality or K-state) for the referential argument of the VP. This corresponds to the operation of existential closure in frameworks such as that of Diesing (1992).23

Having introduced the basic components of the analysis, we can now derive the compositional semantic representation of sentence (50) as in (52):24
a. $\quad\left[{ }_{\mathrm{VP}}\right.$ Carol schlaf-]: $\lambda \mathrm{e}[\mathrm{v} \mid \operatorname{SLEEP}(\mathrm{e}), \operatorname{THEME}(\mathrm{e}, \mathrm{v}), \operatorname{CAROL}(\mathrm{v})]$
b. $\quad\left[_{\text {IP }}\right.$ Carol schläft]: $\left[\mathrm{s}^{\mathrm{e}}, \mathrm{v} \mid \operatorname{SLEEP}(\mathrm{s}), \operatorname{TheME}(\mathrm{s}, \mathrm{v}), \operatorname{CAROL}(\mathrm{v})\right]$

Note that in the course of applying Infl (51c) to an eventuality VP like (51a), the discourse referent $\mathrm{s}$ which ranges originally over eventualities and $\mathrm{K}$-states is narrowed down to the domain of eventualities. This is indicated in (52b) by the addition of a superscript e to s within the universe of discourse. (For the details of functional application and $\lambda$-conversion in DRT, see Asher (1993: 70ff).)

Now, what about copular constructions? I want to propose as a lexical entry for English be, German sein, Spanish ser, and other copula forms the representation given in (52):

$$
\text { be } / \operatorname{sein} / \operatorname{ser} \ldots: \quad \lambda \mathrm{P} \lambda \mathrm{x} \lambda \mathrm{z}[\mathrm{z} \approx[\mathrm{P}(\mathrm{x})]]
$$

According to (53), the contribution of the copula consists in introducing a referential argument $\mathrm{z}$ of type K-state which is characterized by the predicate $\mathrm{P}$ applying to the individual $\mathrm{x}$. Asher (1993: 145f) defines “ $\approx$ " as relating a discourse referent for an abstract object (facts, propositions etc.) to a DRS that characterizes this discourse referent. Further details follow below.

Before turning to the interpretation of (53) let us first have a look at the compositional derivation of the DRS for a copula sentence. Given the sample entries for adjectives, nouns, and prepositions in (54a,b,c), we can construct DRSs for simple copula sentences, as shown in (55)(57). The DRS for a stative verb is provided for comparison in (58).

23 In the notation of predicate logic, the DRS for Infl in (51c) would correspond to (i).

(i) Infl: $\lambda \mathrm{P} \exists \mathrm{s}[\mathrm{P}(\mathrm{s})]$

24 For the present purposes I will assume a VP-internal subject position but nothing hinges on this assumption. 
(54)
a. müde: $\quad \lambda \mathrm{y}[\operatorname{TIRED}(\mathrm{y})]$
b. Vegetarierin: $\lambda \mathrm{y}$ [VEGETARIAN $(\mathrm{y})]$
c. in:
$\lambda \mathrm{x} \lambda \mathrm{y}[\operatorname{LOC}(\mathrm{y}, \mathrm{IN}(\mathrm{x}))]$

(55) a. Carol ist müde.

b. $\left[{ }_{\mathrm{V}}\right.$, müde sei- $]$ : $\quad \lambda \mathrm{x} \lambda \mathrm{z}[\mathrm{z} \approx[\operatorname{TiRED}(\mathrm{x})]]$

c. $\quad{ }_{\mathrm{VP}}$ Carol müde sei-]: $\lambda \mathrm{z}[\mathrm{v} \mid \mathrm{z} \approx[\operatorname{TiRED}(\mathrm{v})], \operatorname{CAROL}(\mathrm{v})]$

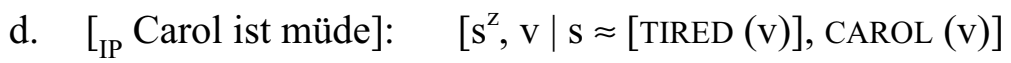

(56) a. Carol ist Vegetarierin.

b. $[\mathrm{V}$, Veg. sei-]: $\quad \lambda \mathrm{x} \lambda \mathrm{z}[\mathrm{z} \approx[\operatorname{Vegetarian}(\mathrm{x})]]$

c. $\quad{ }_{\mathrm{VP}}$ Carol Veg. sei-]: $\quad \lambda \mathrm{z}[\mathrm{v} \mid \mathrm{z} \approx[\operatorname{Vegetarian}(\mathrm{v})]$, CAROL $(\mathrm{v})]$

d. $\quad{ }_{\text {IP }}$ Carol ist Veg.]: $\quad\left[\mathrm{s}^{\mathrm{z}}, \mathrm{v} \mid \mathrm{s} \approx\right.$ [Vegetarian (v)], CAROL (v)]

(57) a. Der Brief war in einem Umschlag. The letter was in an envelope.

b. $\quad{ }_{\mathrm{PP}}$ in einem Umschlag]: $\quad \lambda \mathrm{y}[\mathrm{u} \mid \operatorname{LOC}(\mathrm{y}, \mathrm{IN}(\mathrm{u}))$, ENVELOP $(\mathrm{u})]$

c. $\left[{ }_{\mathrm{V}}\right.$, in einem Umschlag sei-]: $\lambda \mathrm{x} \lambda \mathrm{z}[\mathrm{u} \mid \mathrm{z} \approx[\operatorname{LOC}(\mathrm{x}, \mathrm{IN}(\mathrm{u}))$, $\operatorname{ENVELOP}(\mathrm{u})]]$

d. $\quad{ }_{\mathrm{VP}}$ der Brief in einem Umschlag sei-]: $\lambda \mathrm{z}[\mathrm{v}, \mathrm{u} \mid \mathrm{z} \approx[\operatorname{LOC}(\mathrm{v}, \operatorname{IN}(\mathrm{u})), \operatorname{ENVELOP}(\mathrm{u})], \operatorname{LETTER}(\mathrm{v})]$

e. $\quad\left[_{\mathrm{IP}}\right.$ Der Brief war in einem Umschlag]: $\left[\mathrm{s}^{\mathrm{z}}, \mathrm{v}, \mathrm{u} \mid \mathrm{s} \approx[\operatorname{LOC}(\mathrm{v}, \mathrm{IN}(\mathrm{u})), \operatorname{ENVELOP}(\mathrm{u})], \operatorname{LETTER}(\mathrm{v})\right]$

(58) a. Carol ähnelt Max. Carol resembles Max.

b. ähneln: $\quad \lambda \mathrm{y} \lambda \mathrm{x} \lambda \mathrm{z}[\mathrm{z} \approx[\operatorname{ReSEMBLE}(\mathrm{x}, \mathrm{y})]]$

c. $\left[{ }_{\mathrm{V}}\right.$, Max ähnel-]: $\quad \lambda \mathrm{x} \lambda \mathrm{z}[\mathrm{u} \mid \mathrm{z} \approx[\operatorname{ReSemble}(\mathrm{x}, \mathrm{u})], \operatorname{MAX}(\mathrm{u})]$

d. $\quad[$ VP $\operatorname{Carol~Max~ähnel-]:\lambda z~}[\mathrm{v}, \mathrm{u} \mid \mathrm{z} \approx[\operatorname{Resemble}(\mathrm{v}, \mathrm{u})], \operatorname{MAX}(\mathrm{u}), \operatorname{CAROL}(\mathrm{v})]$

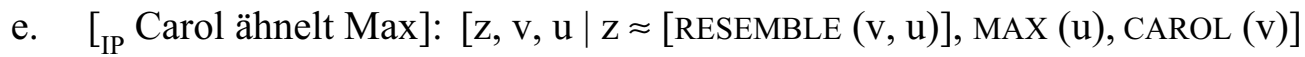

Note that some interesting features of the proposed analysis can be read off these DRSs. First, copular SLPs (55) and copular ILPs (56) display identical argument structures during the whole process of composition. Therefore, as corroborated by our findings in sections 4 and 5.1, copular SLPs and ILPs will not show any grammatically significant differences with respect to, for example, their combination with, circumstantial modifiers, their occurrence in perception reports, and their accessibility for anaphoric reference.

Next, a comparison of (55)-(58) with (52) reveals that the difference between copular constructions and stative verbs, on the one hand, and D-state verbs, on the other, is basically a matter of a sortal contrast, which can be exploited in the course of building up a meaning compositionally. That is, while eventuality arguments are suitable targets for locative modifiers, manner adverbials, and the like, K-state arguments won't tolerate them. The difference disappears as soon as the verb's referential argument is existentially bound by Infl. 
Finally, it is worth pointing out that the definition of K-states as abstract objects that have no location in space (see (48)) does not exclude copula sentences with locative main predicates, as illustrated in (57). Like any other copula construction, locative varieties assign a property to the subject referent. In the case of locative main predicates, this is the property of being located in the spatial region designated by the PP. That is, locative copula sentences do not locate some hidden state argument, but the object (or eventuality) referred to by the subject referent, as in $(57 \mathrm{e})$.

To sum up our results so far, the above DRSs offer a description of copula sentences as introducing a $\mathrm{K}$-state $\mathrm{z}$ into the universe of discourse. This $\mathrm{K}$-state is characterized by a DRS built up from the main predicate applying to the subject referent. The K-state $\mathrm{z}$ is a suitable target for temporal modifiers (as well as for tense and aspect; see Maienborn 2003d) and can be anaphorically referred to in the discourse.

Now, how should these DRSs be interpreted? First, in order to add the category of Kstates, the syntactic well-formedness conditions for DRSs (Asher 1993: 95f) must be augmented by the following condition:

Syntactic well-formedness condition for DRSs:

If $\mathrm{z}$ is a discourse referent of type K-state and $\mathrm{X}$ is a DRS, then $\mathrm{z} \approx \mathrm{X}$ is a DRS condition.

Next, the respective semantic interpretation is given by adding (60) to the existing set of conditions on DRS embedding (Asher 1993: 97).25 (The function $\tau(\mathrm{s})$ maps eventualities and Kstates onto the time interval they occupy.)

DRS embedding:

If $\psi$ is a DRS condition of the form $\mathrm{z} \approx \mathrm{X}$, then $\psi$ is satisfied in a model $\mathrm{M}$ with respect to $\mathrm{w}, \mathrm{t}$ and an embedding function $\mathrm{f}$, just in case $\mathrm{f}$ embeds $\mathrm{X}$ in $\mathrm{M}$ relative to $\mathrm{w}, \mathrm{t}$ with $\mathrm{t}=\tau(\mathrm{z})$.

Thus, disregarding relativization to possible worlds, a DRS condition $\mathrm{z} \approx \mathrm{X}$ is satisfied if there is an embedding for $\mathrm{X}$ at $\tau(\mathrm{z})$. Take, for example, our sample sentence (50), repeated below:

(61) a. Carol ist müde.

b. $\quad[\mathrm{z}, \mathrm{v} \mid \mathrm{z} \approx[\operatorname{TIRED}(\mathrm{v})]$, CAROL $(\mathrm{v})]$

Sentence (61a) is true in a model $M$ if there is an embedding for (61b) in $M$ that maps the discourse referent $\mathrm{v}$ onto an individual named Carol, to which the property of being tired applies at the time $\tau(\mathrm{z})$.

This description of the interpretation of DRSs containing K-state referents is still a preliminary one, which is still in need of refinement. In particular, the well-formedness condition (59) allows K-state referents to be characterized by any kind of DRS. This is obviously too liberal and must be restricted appropriately - a task that must be left for future research.

25 There might be alternative solutions - see particularly Asher's (1993: 407, 427) remarks on weak versus strong representationalism, which affect the interpretation of " $\approx$ " - but for reasons of space I must leave discussion of these aside here. 


\section{Some implications for Davidsonian eventualities}

By way of conclusion I wish to make two additional remarks, which suggest that K-states not only fare better than Davidsonian eventualities for the analysis of copula sentences but may also simplify our assumptions about these eventualities. These remarks concern closure conditions and the latent infinite regress of eventualities.

\subsection{Closure conditions}

On the received view, there is a split within the category of eventualities with respect to closure conditions: states but not events are closed under complementation (e.g. Herweg (1991), Asher $(1993,2000))$. The distinction between K-states and D-states advocated here calls for a more careful inspection of the relevant data. In fact, it turns out that only K-states are closed under negation, as (62) indicates. The denotatum of Carol was in the studio and its negation are both K-states. As such they can be combined, for example, with temporal modifiers. 26

$$
\begin{aligned}
& \text { Carol war (nicht) im Studio, und zwar eine Stunde lang. } \\
& \text { Carol was (not) in.the studio, "in fact" for one hour. }
\end{aligned}
$$

D-states, on the other hand, pattern with events and processes. (63) illustrates the behavior of events. The result of negating The train arrived does not express an event anymore. Thus, the addition of, for example, a locative modifier or a manner adverbial is excluded. Our category of $\mathrm{D}$-states shows exactly the same behavior. Once we negate a D-state verb, locative modifiers or manner adverbials aren't acceptable anymore, as (65) shows. (Ability to occur with temporal modifiers does not discriminate between K-states and D-states and therefore is not a reliable diagnostic for D-states; see section 5.1.)

(63) Der Zug ist (*nicht) angekommen, und zwar auf Gleis drei / pünktlich. events The train did (*not) arrive, "in fact" on platform three / on time.

(64) Eva aß (*nicht) Pizza, und zwar gierig / im Garten / mit Renate. Eva ate (*not) pizza, "in fact" greedily / in.the garden / with Renate.

(65) Paul wartete (*nicht) auf den Bus, und zwar dort / lässig / mit Carol. Paul waited (*not) for the bus, "in fact" there / coolly/ with Carol.

processes

D-states

The above discussion of (62)-(65) shows that once we disentangle D-states as a subtype of eventualities from K-states, the category of eventualities turns out to behave more uniformly than generally assumed. Thus, we may conclude that there is no split within the category of eventualities with respect to closure under complementation.

26 German und zwar 'in fact' is a means of attaching VP-modifiers sentence-finally. This reduces the risk of confusing sentence negation with constituent negation. 


\subsection{Latent infinite regress of eventualities}

The second remark is related to a latent problem with the Davidsonian paradigm, which has so far received little attention. This concerns sentences like (66) and eventuality-based semantic representations for them like (67), as described in section 3 above.

(66) Carol is tired.

(67) $\exists$ e [TIRED (e) \& THEME (e, carol)]

(67) indicates that there is an eventuality of tiredness and Carol is its theme. That is, the fact that Carol has a certain property apparently suffices to introduce an eventuality e. But what prevents us from taking the fact that e has a certain property to introduce another eventuality? That is, why can't we replace (67) with (68) - and then go on even further, creating an infinite regress of eventualities?27

$$
\text { ヨee' [Be-TiRed (e') \& Theme (e', e) \& Theme (e, carol)] }
$$

A similar problem arises in the case of adverbial modification. It is not clear why a sentence like (69) should be given an analysis like (69a) instead of (69b).

(69) Carol was driving quickly.

a. $\quad \exists$ e [DRIVE (e) \& AGENT (e, carol) \& QUICK (e)]

b. ヨee' [DRIVE (e) \& AGENT (e, carol) \& QUiCK (e') \& ThEME (e', e)]

This dilemma is acknowledged by Geuder (2000):

It is a puzzle of neo-Davidsonian semantics that predication of an individual can define a state, but the otherwise similar predication of an eventuality never does; still we have to accept it as a matter of fact.

Geuder (2000: 104)

In my view, this is not a matter of fact - an empirical issue - but a weakness of the theory caused by stretching the notion of eventualities too far. What we are confronted with here is the price of assuming that predication is inherently eventuality-related. Under the account developed here, simple predication does not suffice to define a D-state. So, there is no risk of running into an infinite regress of eventualities.

What about K-states? Could they become subject to infinite regress? That is, how do we exclude (70) as a semantic representation for (66)?

$$
\left[\mathrm{z}^{\prime}, \mathrm{z}, \mathrm{v} \mid \mathrm{z}^{\prime} \approx[\mathrm{z} \approx[\operatorname{TIRED}(\mathrm{v})]], \mathrm{CAROL}(\mathrm{v})\right]
$$

First, within the analysis proposed here there is no way to derive structures like (70) compositionally. K-states are not introduced by arbitrary predicates but originate as referential arguments of the copula. Given this, it would be attractive to have a more restrictive formal system that excludes representations like (70) as syntactically ill-formed right from the start. This

27 To my knowledge, Bennett (1988: 177) was the first to raise this criticism. 
could be achieved by imposing further structural restrictions on admissible DRSs for characterizing K-states, along the lines that I suggested at the end of section 5.

The starting point for the present study was Davidson's (1980: 137) claim that "there is a lot of language we can make systematic sense of if we suppose events exist". I hope to have shown that - changing Davidson's slogan somewhat - there is also a lot of language that we can make systematic sense of if we stop misusing event(ualitie)s.

On the one hand, introducing Kimian states as a supplement to, rather than a substitute for, Davidsonian eventualities enables us to account for the linguistic behavior of copular constructions (as regards, for example, anaphoric reference and occurrence with temporal modifiers) as well as for the differences between copular constructions and eventuality expressions (as regards, for example, their acceptability as infinitival complements of perception verbs and occurrence with locative modifiers, manner adverbials).

On the other hand, taking some load off of eventualities allows us to stick to a wellmotivated understanding of them as spatiotemporal entities (with functionally integrated participants) and to simplify some of our assumptions about their logical properties.

\section{References}

ASHER, Nicholas (1993). Reference to Abstract Objects in Discourse. Dordrecht: Kluwer

ASHER, Nicholas (2000). Events, Facts, Propositions, and Evolutive Anaphora. In: J. HIGGINBOTHAM, F. PIANESI \& A. VARZI (eds.), pp.123-150

BACH, Emmon (1986). The Algebra of Events. Linguistics and Philosophy, 9, pp. 5-16

BENNETT, Jonathan (1988). Events and their Names. Indianapolis, Cambridge, Mass.: Hackett

BIERWISCH, Manfred (1988). On the Grammar of Local Prepositions. In: M. BIERWISCH, W. MOTSCH \& I. ZIMMERMANN (eds.). Syntax, Semantik und Lexikon (pp. 1-65). Berlin: Akademie-Verlag

BLUTNER, Reinhard (2000). Some Aspects of Optimality in Natural Language Interpretation. Journal of Semantics, 17, pp. 189-216

CARLSON, Gregory N. (1977). Reference to Kinds in English, University of California: Ph.D. Diss

CARLSON, Gregory N. (1998). Thematic Roles and the Individuation of Events. In: S. ROTHSTEIN (ed.). Events and Grammar (pp. 35-51). Dordrecht: Kluwer

CHIERCHIA, Gennaro (1995). Individual-Level Predicates as Inherent Generics. In: G. N. CARLSON \& F. J. PELLETIER (eds.). The Generic Book (pp. 176-223). Chicago, London: The University of Chicago Press

DAVIDSON, Donald (1967). The Logical Form of Action Sentences. In: N. RESHER (ed.). The Logic of Decision and Action (pp. 81-95). Pittsburgh: University of Pittsburgh Press

DAVIDSON, Donald (1969). The Individuation of Events. In: N. RESHER et al. (eds.). Essays in Honor of Carl G. Hempel (pp. 216-234). Dordrecht: Reidel

DAVIDSON, Donald (1980). The Logical Form of Action Sentences: Criticism, Comment, and Defence. In: D. DAVIDSON (ed.). Essays on Actions and Events (pp. 105-148). Oxford: Clarendon Press

DIESING, Molly (1992). Indefinites. Cambridge, Mass.: The MIT Press

DÖLLING, Johannes (1999). Kopulasätze als Zustandsbeschreibungen. ZAS Papers in Linguistics, 14, pp. 95-122

DOWTY, David R. (1979). Word Meaning and Montague Grammar. Dordrecht: Reidel 
ECKARDT, Regine (1998). Adverbs, Events and Other Things. Issues in the Semantics of Manner Adverbs. Tübingen: Niemeyer

ENGELBERG, Stefan (2000). Verben, Ereignisse und das Lexikon. Tübingen: Niemeyer

FERNALD, Theodore B. (2000). Predicates and Temporal Arguments. Oxford, New York: Oxford University Press

FREY, Werner (2000). Über die syntaktische Position der Satztopiks im Deutschen. ZAS Papers in Linguistics, 20, pp. 137-172

FREY, Werner (2003). Syntactic conditions on adjunct classes. In: E. LANG, C. MAIENBORN \& C. FABRICIUS-HANSEN (eds.), pp. 163-210

FREY, Werner \& PITTNER, Karin (1998). Zur Positionierung der Adverbiale im deutschen Mittelfeld. Linguistische Berichte, 176, pp. 489-534

GEUDER, Wilhelm (2000). Oriented Adverbs. Issues in the Lexical Semantics of Event Adverbs. Universität Tübingen: Diss

HERWEG, Michael (1991). Perfective and Imperfective Aspect and the Theory of Events and States. Linguistics, 29, pp. 969-1010

HIGGINBOTHAM, James (1983). The Logic of Perceptual Reports: An Extensional Alternative to Situation Semantics. Journal of Philosophy, 80, pp. 100-127

HIGGINBOTHAM, James (1985). On Semantics. Linguistic Inquiry, 16, pp. 547-593

HIGGINBOTHAM, James (2000). On Events in Linguistic Semantics. In J. HIGGINBOTHAM, F. PIANESI \& A. VARZI (eds.), pp. 49-79

HIGGINBOTHAM, James \& RAMCHAND, Gillian (1997). The Stage-Level/Individual-Level Distinction and the Mapping Hypothesis. Oxford University Working Papers in Linguistics, Philology \& Phonetics, 2, pp. 53-83

HIGGINBOTHAM, James \& PIANESI, Fabio \& VARZI, Achille (2000) (eds.). Speaking of Events. Oxford, New York: Oxford University Press

JÄGER, Gerhard (2001). Topic-Comment Structure and the Contrast between Stage Level and Individual Level Predicates. Journal of Semantics, 18, pp. 83-126

KAMP, Hans (1981). A Theory of Truth and Semantic Representation. In: J. GROENENDIJK, T. JANSSEN \& M. STOKHOF (eds.). Formal Methods in the Study of Language (pp. 277-322). Amsterdam: Mathematisch Centrum

KAMP, Hans \& REYLE, Uwe (1993). From Discourse to Logic: Introduction to Modeltheoretic Semantics of Natural Language, Formal Logic and Discourse Representation Theory. Dordrecht: Kluwer

KATZ, Graham (2000). Anti Neo-Davidsonianism: Against a Davidsonian Semantics for State Sentences. In: C. TENNY \& J. PUSTEJOVSKY (eds.). Events as Grammatical Objects (pp. 393-416). Stanford, CA: CSLI Publications

KATZ, Graham (2003). Event arguments, adverb selection, and the Stative Adverb Gap. In: E. LANG, C. MAIENBORN \& C. FABRICIUS-HANSEN (eds.), pp. 455-474

KIM, Jaegwon (1969). Events and their Descriptions: Some Considerations. In: N. RESHER et al. (eds.). Essays in Honor of Carl G. Hempel (pp. 198-215). Dordrecht: Reidel

KIM, Jaegwon (1976). Events as Property Exemplifications. In: M. BRAND \& D. WALTON (eds.). Action Theory: Proceedings of the Winnipeg Conference on Human Action (pp. 159-177). Dordrecht: Reidel

KLEIN, Wolfgang (1994). Time in Language. London, New York: Routledge

KRATZER, Angelika (1995). Stage-Level and Individual-Level Predicates. In: G. N. CARLSON \& F. J. PELLETIER (eds.). The Generic Book (pp. 125-175). Chicago, London: The University of Chicago Press 
KRIFKA, Manfred (1989). Nominal Reference, Temporal Constitution and Quantification in Event Semantics. In: R. BARTSCH, J. van BENTHEM \& P. VAN EMDE BOAS (eds.). Semantics and Contextual Expression (pp. 75-115). Dordrecht: Foris

KRIFKA, Manfred (1998). Scope Inversion under the Rise-Fall Contour in German. Linguistic Inquiry, 29/1, pp. 75-112

LAKOFF, George (1966). Stative Adjectives and Verbs in English. Report No. NSF-17, The National Science Foundation, Mathematical Linguistics and Automatic Translation (pp. 1-16). Cambridge, Mass

LANG, Ewald \& MAIENBORN, Claudia \& FABRICIUS-HANSEN, Cathrine (2003)(eds.). Modifying Adjuncts. Berlin: Mouton de Gruyter

LEMMON, E. J. (1967). Comments on D. Davidson's "The Logical Form of Action Sentences". In: N. RESHER (ed.). The Logic of Decision and Action (pp. 96-103). Pittsburgh: University of Pittsburgh Press

LEPORE, Ernest (1985). The Semantics of Action, Event, and Singular Causal Sentences. In: E. LEPORE \& B. MCLAUGHLIN (eds.). Actions and Events: Perspectives on the Philosophy of Donald Davidson (pp. 151-161). Oxford: Blackwell

LOMBARD, Lawrence B. (1998). Ontologies of Events. In: S. LAURENCE \& C. MACDONALD (eds.). Contemporary Readings in the Foundations of Metaphysics (pp. 277-294). Oxford: Blackwell

MAIENBORN, Claudia (2001). On the Position and Interpretation of Locative Modifiers. Natural Language Semantics, 9, 191-240

MAIENBORN, Claudia (2003a). Die logische Form von Kopula-Sätzen (studia grammatica 56). Berlin: Akademie-Verlag

MAIENBORN, Claudia (2003b). Against a Davidsonian Analysis of Copula-Sentences. In: M. KADOWAKI \& S. KAWAHARA (eds.). NELS 33 Proceedings (pp. 167-186). Amherst: GLSA

MAIENBORN, Claudia (2003c). Event-internal modifiers: Semantic underspecification and conceptual interpretation. In E. LANG, C. MAIENBORN \& C. FABRICIUS-HANSEN (eds.), (pp. 475-509)

MAIENBORN, Claudia (2003d). A discourse-based account of Spanish ser/estar. To appear in: Linguistics

MAIENBORN, Claudia (2003e). On Davidsonian and Kimian states. To appear in: I. COMOROVSKI \& K. v. HEUSINGER (eds.). Existence: Semantics and Syntax. Dordrecht: Kluwer

MAIENBORN, Claudia (2004). A Pragmatic Explanation of the Stage Level/Individual Level Contrast in Combination with Locatives. To appear in: B. TUCKER (ed.). WECOL 2003 Proceedings. Tucson

MCNALLY, Louise (1998). Stativity and Theticity. In: S. ROTHSTEIN (ed.). Events and Grammar (pp. 293-307). Dordrecht: Kluwer

MILSARK, Gary L. (1974). Existential Sentences in English, MIT: Ph.D. Diss

MILSARK, Gary L. (1977). Toward an Explanation of Certain Peculiarities of the Existential Construction in English. Linguistic Analysis, 3, pp. 1-29

PARSONS, Terence (1990). Events in the Semantics of English. A Study in Subatomic Semantics. Cambridge, Mass.: The MIT Press

PARSONS, Terence (2000). Underlying States and Time Travel. In: J. HIGGINBOTHAM, F. PIANESI \& A. VARZI (eds.), pp. 81-93

PIANESI, Fabio \& VARZI, Achille C. (2000). Events and Event Talk: An Introduction. In: J. HIGGINBOTHAM, F. PIANESI \& A. VARZI (eds.), pp. 3-47 
RAMCHAND, Gillian C. (1996). Two Subject Positions in Scottish Gaelic: The SyntaxSemantics Interface. Natural Language Semantics, 4, pp. 165-191

RAPOSO, Eduardo \& URIAGEREKA, Juan (1995). Two Types of Small Clauses (Toward a Syntax of Theme/Rheme Relations). In: A. CARDINALETTI \& M.T. GUASTI, (eds.). Small Clauses (pp. 179-206). New York: Academic Press

ROTHSTEIN, Susan (1999). Fine-grained Structure in the Eventuality Domain: The Semantics of Predicative Adjective Phrases and Be. Natural Language Semantics, 7, pp. 347-420

VENDLER, Zeno (1967). Linguistics in Philosopy. Ithaca, New York: Cornell University Press 